\title{
Submission of Electronic Evidence in General Crimes and Special Crimes
} Margie Gladies Sopacua*

Faculty of Law, Pattimura University, Indonesia

DOI: $\underline{10.36348 / \text { sijlcj.2020.v03i04.006 }}$

| Received: 01.04.2020 | Accepted: 08.04.2020 | Published: 14.04.2020

*Corresponding author: Margie Gladies Sopacua

\section{Abstract}

In the case of Proof, there are several provisions governing evidence related to the provisions of the statutory provisions and are used by judges to prove what is being wrongly accused based on the applicable law and the judge's own conviction. Article 184 of the Criminal Procedure Code, regulates legal evidence, including witness statements, expert statements, letters, instructions and statements of the defendant. In accordance with what has been regulated in Article 184 of the Criminal Procedure Code, it can be said that the submission of evidence in the form of electronic documents in a general criminal case or special criminal case can be used as legal evidence, this can be seen by the expansion of the evidence contained in Article 5 paragraph (1) of the Information and Electronic Transactions Law and Article 26 A of Law Number 19 Year 2016 concerning Amendments to Law Number 11 of 2008, and Article 12 Paragraph (1) of Law Number 30 Year 2002 concerning the Corruption Eradication Commission jo. Law Number 19 Year 2019 which explicitly regulates the authority to conduct wiretapping conducted by the Corruption Eradication Commission. For this reason, it is hoped that the government will immediately ratify the Criminal Procedure Code in the future because Article 175 of the Criminal Procedure Draft is included in the legal evidence added to the judge's observation.

Keywords: Electronic Evidence, General Criminal Case, Special Criminal Case.

Copyright @ 2020: This is an open-access article distributed under the terms of the Creative Commons Attribution license which permits unrestricted use, distribution, and reproduction in any medium for non-commercial use (NonCommercial, or CC-BY-NC) provided the original author and source are credited.

\section{INTRODUCTION}

Indonesia is a constitutional or constitutional state that is a country that is limited by the constitution [1]. This means that Indonesia is a rule of law state that has been regulated and mandated by the 1945 Constitution of the Republic of Indonesia in Article 1 paragraph (3). As a consequence of Indonesia as a state of law, from the mandated regulation, that is, all living arrangements in terms of community, nation and state life must be guided by these legal norms.

Legal norms are social rules made by certain institutions in this case the Government, so it explicitly prohibits and forces people to act in accordance with the wishes of the regulators themselves. Legal norms are made as written rules or agreements that have sanctions and enforcement tools. The aim is for the community to obey it and feel deterrent with the sanctions applied, so as not to repeat acts that violate the law a second time [2]. The intended legal norms can be seen specifically regulated in public law, namely Law Number 1 of 1946 concerning the Criminal Code which is then applied and enforced by law applied in criminal procedural law governed by the Law No. 8 Year 1981 concerning the Criminal Procedure Code.
The legal norms that have been stated above in the development of the current era of implementation and enforcement will be faced with technological crimes that will have an impact on and influence of these norms. This can be seen in the development of the globalization era at this time which is quite influential so that it has a big impact in the order of an organizational life and social relations between the people, so that it can produce a new legal norms and also new values and develops in social life caused by the progress and development of technology that is happening now.

Current technological advances have developed so rapidly. Technology which is a product of modernity has experienced extraordinary leaps. Because so rapidly, in turn, the creator of technology itself is confused to control it, it can even be said to turn around controlling humans [3]. Technological developments have driven behavioral change and one of them is dependence on technology itself. Whether we realize it or not, the change in society from bassed paper to papper society is becoming increasingly clear [4]. Based on this understanding, it can be seen that people begin to interact and communicate using mobile phones 
in this case such as mobile phones or virtual electronic mail.

Crime basically grows and develops in society, there is no crime without society or what lacassagne said that society has criminals according to their services. However we know a lot about the factors of crime that exist in society, but what is certain is that crime is a form of human behavior whose development continues to be parallel to the development of society itself. Therefore crime has been accepted as a fact, both in the simplest of society and in a modern society, which is detrimental to society [5].

Examination of a case from a criminal act in a court of law is a stage in the enforcement of criminal law in concreto, namely the application of material criminal law in real life in society. This stage starts from the submission of the indictment by the public prosecutor to the judge's decision in the trial. Investigation of a criminal offense by a person can be carried out by a judge, namely carrying out the stage of proof as a basis in determining whether a person's criminal actions can be found guilty or not.

The criminal procedure code as one of the instruments in the criminal justice system basically has the main function, namely [6]:

1. Search for and find truth;

2. Decision making by judges and

3. Implementation of the decision that has been taken.

Of the three functions, the most important is the function to search for and find truth. The intended truth is the material truth, the truth which is as complete as possible or at least approaches the truth of a criminal case by applying the provisions of the criminal procedure law honestly and precisely [7]. The purpose of criminal procedure law is to seek and find the final truth, which is the goal of all national legal order, in this case achieving an orderly, peaceful, just and prosperous society [8]. Andi Hamzah argued, that proving whether or not the defendant committed the act committed was the most important part of the criminal procedure [9].

When examined from the perspective of the criminal justice system in general and criminal procedural law (formeel strafrecht/straf procesrecht) in particular, the aspect of proof plays the role of determining the conviction to declare someone's guilt so that a criminal convicted by a judge [10].

In the case of Proof, there are several provisions governing evidence related to the provisions of the statutory provisions and are used by judges to prove what is being wrongly accused based on the applicable law and the judge's own conviction. The Criminal Procedure Code stipulates that judges must not impose a crime on a person except if with at least two valid evidences, the judge in this case obtains the conviction that a criminal act actually occurred and the defendant is guilty of committing it. Article 184 of the Criminal Procedure Code, regulating legal evidence, is (1) Witness statement; (2) Expert statement; (3) Letter; (4) Instructions; and (5) Defendant's statement. Based on this, the problem that will be discussed in this paper is how is whether submission of evidence in the form of electronic documents in a general criminal case and special criminal case can be used as valid evidence?

\section{DISCUSSION}

\section{Electronic Document Evidence in General Crimes and Special Crimes}

Along with the development of society in the world of information technology with the presence of the internet in human life, correspondence that was traditionally done or through the post office, can now be done simply by sitting and typing the letter in front of a computer or mobile phone. Likewise with the rise of social networks like Facebook, Twitter, Intstagram and MySpace making cyberspace a meeting place for people around the world, information technology plays an important role, both in the present and in the future [11].

The presence of electronic evidence in the life of criminal law enforcement has caused controversy. Electronic evidence arrangements are not contained in the Criminal Procedure Code, but only regulated in specific laws. Regarding electronic evidence, there are those who question their status when used to prove general criminal offenses in court, for example the use of Closed-Circuit Television (CCTV) to prove criminal offenses in the Jessica case. From these circumstances, the authors are interested in examining more closely related to electronic evidence as legal evidence in criminal procedural law.

Evidence has a very important function in the examination of a criminal case. According to Law No. 8 Year 1981 concerning the Criminal Procedure Code known evidence in the form of movable and immovable, tangible and intangible objects[12]. H.A.R. Pontoh in the Criminal Procedure Study Material Series at the Sam Ratulangi University Faculty of Law writes: A criminal case with evidence will be able to speed up the process of settling a case than another case that has no evidence, because with the evidence presented before the Judge can add or strengthen the judge's conviction about the defendant's guilt and can also be used as an element of aggravating or alleviating the sentence to be imposed [13].

Relating to evidence as stated earlier that in accordance with the provisions of Article 184 which regulates that the evidence consists of; Witness statements, expert statements, letters, instructions, and statements of the defendant, the position of electronic evidence cannot be classified in the types of legal 
evidence. In accordance with Article 184 of the Criminal Procedure Code.

Submission of evidence of electronic documents in cases of general criminal offenses and special criminal offenses must refer to Article 184 of the Criminal Procedure Code regarding valid evidence such as witness statements, expert statements, letters, instructions and statements of the accused.

The requirements must be met so that evidence can be submitted:

1. Material and Formal Requirements;

2. Must be competent;

3. Must be relevant.

Formal requirements in Article 5 paragraph (4) of the Information and Electronic Transactions Law (ITE Law), namely that electronic document information is not a document or letter which according to the legislation must be in written form. Whereas the material requirements are stipulated in Article 6, Article 15, Article 16 of the ITE Law, which essentially Information and Electronic Documents must be guaranteed the authenticity, integrity and availability. To guarantee the fulfillment of the material requirements referred to in many ways digital forensics is needed. Whereas competent and relevant means that the evidence has the competence submitted to prove the occurrence of a crime and possess relevance to the crime so as to convince the judge to impose a crime.

Every state loss is caused by perpetrators of corruption, both those that are still in the country and those already outside the country must be returned, through the mechanism of international cooperation which is an absolute thing to do[14]. However, there is an expansion related to electronic evidence, which can be seen in several specific laws and regulations including the following;

1. Law No. 31 Year 1999 concerning Eradication of Corruption Crimes as amended by Law No. 20 Year 2001,

2. Law Number 11 Year 2008 concerning Information and Electronic Transactions as amended by Law Number 19 Year 2016

In terms of history, efforts to find out confidential information from other people or other parties or groups for personal gain are not really new, but it should be stated that the process or method used to obtain confidential information from other parties mentioned above would have been experiencing development.

Wiretapping is one of the methods used by law enforcement agencies provided by legislation such as the law on corruption eradication as part of the investigation, investigation and evidence [15]. Article 12A Law No. 31 Year 1999 concerning Eradication of
Corruption Crimes as amended by Law No. 20 Year 2001 regulates wiretapping.

Furthermore Article 26A of Law No. 20 Year 2001 concerning the Eradication of Corruption Crimes stipulates that "Legal evidence in the form of instructions as referred to in Article 188 paragraph (2) of the Criminal Procedure Code, specifically for acts of corruption can also be obtained;

a. Other evidence in the form of information that is spoken, sent, received or stored electronically with optical devices or similar to that;

b. Documents, namely any recorded data or information that can be seen, read and or heard that can be issued with or without the help of a means, whether stated on paper, any physical object other than paper, any physical object other than paper, or recorded electronically, in the form of writing, pictures, maps, designs, photographs, letters, signs, numbers or perforations that have meaning".

If the provisions of Article 188 paragraph (1) and paragraph (2) of the Criminal Procedure Code are related to Article 26A of Law No. 20 Year 2001, currently evidence for evidence comes from witness statements, letters, defendant statements, and electronic evidence in the form of information and documents. However, electronic evidence can also be used as a source of instructions, i.e. printed information or electronic documents can be categorized as letters. The intended letter is "another letter" as long as the letter has a relationship with the contents of the other evidentiary tools as referred to in Article 187 letter d.

Law No. 30 Year 2002 concerning the Corruption Eradication Commission (as amended by Law Number 19 Year 2019), explicitly regulates the authority to conduct wiretapping conducted by the Corruption Eradication Commission, it is regulated in Article 12 paragraph (1) regulating that "In implementing investigation and prosecution as referred to in article 6 letter e, the corruption eradication commission is authorized to conduct wiretapping”.

Legalization of Law Number 19 Year 2016 Regarding Amendments to Law Number 11 Year 2008 concerning Information and Electronic Transactions, we can see that there is an expansion of evidence as contained in Article 5 paragraph (1) which regulates that "Electronic Information and/or Electronic documents and/or printouts are evidence" and paragraph (2) regulates that "Electronic Information and/or electronic documents and/or printouts as referred to in paragraph (1) are extensions of valid evidence in accordance with the provisions of procedural law prevailing in Indonesia. 
Article 1 number 1 of the ITE Law provides the definition of electronic information is one or a collection of electronic data, including but not limited to writing, sound, images, maps, designs, photographs, electronic data interchange (EDI), electronic mail, telegram, telex, telecopy or the like, letters, signs, numbers, access codes, symbols, or processed perforations that have meaning or can be understood by people who are able to understand them [16].

Article 1 number 4 of the ITE Law stipulates that Electronic Documents are; "Any electronic information created, transmitted, sent, received or stored in analog, digital, electromagnetic, optical or the like, which can be seen, displayed and/or heard through a computer or electronic system, including but not limited to writing, sounds, pictures, maps, designs, photographs or the like, letters, signs, numbers, access codes, symbols or perforations that have meaning or meaning or can be understood by people who are able to understand it" [16].

Based on Article 5 paragraph (1) jo Article 44 of Law No. 11 Year 2008, regarding Information and Electronic Transactions, the status of electronic evidence is independent evidence and is an extension of legal evidence as regulated in criminal procedure law in force in Indonesia, so that it can be used as evidence at trial.

Crime is an act that damages the state order and disturbs order in society [17]. Letter of the Supreme Court to the Minister of Justice dated January 14, 1988 No. 39/ TU/88/102/Pid expressed their opinion, that microfilm or microfiche can be used as legal evidence in criminal cases in court replacing documentary evidence, provided that the microfilm's record was previously guaranteed for authenticity which can be traced back from registration or minutes. If the opinion of the Supreme Court in his letter is accepted, then in accordance with the opinion of Paton who stated that the evidence can be [18]:

1. Oral, the words spoken in the trial, witness statements, expert statements, and the defendant's statement.

2. Documentary, which is a letter.

3. Demonstrative evidence, which is material evidence is other physical goods, such as microfilm and microfiche.

Based on what has been stated before by the Supreme Court, then the position of electronic evidence in the form of microfilm or microfiche is valid evidence and its status as a substitute for letter evidence. Thus, it can be said that electronic evidence (microfilm or microfiche) functions for example such as letters.
The draft Criminal Procedure Code in December 2012 Article 175 governing evidence, including:

1. Evidence;

2. Letters;

3. Electronic evidence;

4. Expert statement;

5. Witness statement;

6. Defendant's statement;

7. Judge Observations

The definition of electronic evidence set forth in Article 175 of the Draft Criminal Procedure Code is information that is said to be sent, received or stored electronically with optical devices or similar, including any recorded data or information seen, read or heard, which can be issued with or without assistance a good means contained on paper, any physical object other than paper or electronically stressed in the form of writing, drawings, maps, designs. Photos, letters, signs, numbers, which have meaning.

Electronic evidence can be explicitly seen that it has not been regulated in the Criminal Procedure Code but in the practice of justice in the State of Indonesia both general and special criminal cases many Judges have decided to place electronic evidence as a legal basis for judges' consideration in deciding a general or special criminal case and has become a jurisprudence. What is meant by jurisprudence is a Judge's Decision.

\section{CONCLUSION}

Submission of evidence in the form of electronic documents in a general criminal case and special criminal case can be used as legal evidence as regulated in Article 184 of the Criminal Procedure Code, although electronic evidence is not regulated in that article but there is an expansion of the evidence contained in Article 5 Paragraph (1) of the ITE Law and Article 26A of Law Number 19 Year 2016 concerning Amendments to Law Number 11 Year 2008, as well as Article 12 of Paragraph (1) of Law No. 30 Year 2002 concerning the Corruption Eradication Commission, Law Number 19 Year 2019 which explicitly regulates the authority to conduct wiretapping conducted by the Corruption Eradication Commission. In proving the existence of a case of general or special criminal offenses still adhere to the provisions of formal requirements and material requirements in accordance with applicable laws and regulations in addition to that they must also have the competence and relevance to the crime. For this reason, the government must immediately ratify the Draft Penal Code, in which electronic evidence has been regulated and a judge's observation is added. 


\section{REFERENCES}

1. Jimmy, A. (2010). Pengantar Ilmu Hukum Tata Negara (Introduction to State Administration Law), Rajawali Press, Jakarata, 281.

2. Margie, G. S. (2019). Reformulasi Kaidah Hukum Pencegahan Tindak Pidana Kekerasan Dalam Runah Tangga (Reformulation of the Rules of Prevention of Crimes in Domestic Violence), Dissertation, Faculty of Law, Hasanuddin University, Makassar, 30.

3. Abdul, W., \& Mohammad, L. (2005). Kejahatan Mayantara (Cybercrime), PT. Refika Aditama, Bandung, 59.

4. Josua, S. (2012). Cyberspace, Cybecrime, Cyberlaw, Tatanusa, Jakarta, 262.

5. Budi, S. (2013). Tindak Pidana Elektronik Informasi (Cybercrime), Urgensi Pengaturan Celah Hukumnya (Electronic Information Crime (Cybercrime), Urgency in Legal Gap Settings), Rajawali Press, Jakarta, 21.

6. Achmad, R., \& Soema Di Pradja, S. (1981). Pokok-Pokok Hukum Acara Pidana Indonesia (Principles of Indonesian Criminal Procedure Law), Alumni, Bandung, 4.

7. Andi, H. (1996). Hukum Acara Pidana Indonesia (Indonesian Criminal Procedure Law), CV Sapta Artha Jaya, Jakarta, 7.

8. Nico, N. (1984). Mengenai Hukum Acara Pidana; bagian Umum dan Penyidikan (Regarding Criminal Procedure Law; General and Investigation Section), Liberty, Yogyakarta, 7.

9. Andi, H. (2014). Hukum Acara Pidana Indonesia (Indonesian Criminal Procedure Law), Sinar Grafika, Jakarta, 249.

10. Lilik, M. (2012). Hukum Acara Pidana: Normatif, Teoretis, Praktik dan Permasalahannya (Criminal Procedure Law: Normative, Theoretical, Practical and Problems), Alumni, Bandung, 158.

11. Soesilo, R. (1988). Kitab Undang-Undang Hukum Pidana/KUHP serta Komentar-komentarnya Lengkap pasal Demi Pasal (The Criminal
Code/KUHP and its Comments are complete Article by Article), Politeia, Bogor, 195.

12. Departemen Kehakiman Republik Indonesia (1982). Pedoman Pelaksanaan Kitab UndangUndang Hukum Acara Pidana (Guidelines for Implementing the Criminal Procedure Code), Jakarta, 47.

13. Pontoh, H. A. R. (1989). Rangkaian Bahan Kuliah Hukum Acara Pidana (Criminal Procedure Law Material Series), Fakultas Hukum, Universitas Sam Ratulangi, Manado, 36.

14. Kadarudin. (2015). Asset Recovery Hasil Kejahatan Korupsi: Upaya Pengembalian Kerugian Keuangan Negara Melalui Kerjasama Internasional (Asset Recovery as a Result of Corruption Crimes: An Effort to Recover State Financial Losses Through International Cooperation), Pustaka Pena Press, Makassar, 87.

15. Rezky, M. S. (2018). Legalitas Alat Bukti Elektronik Hasil Penyadapan dalam Rencana Penjebakan Sebagai Upaya Penegakan Hukum (The Legality of Electronic Evidence Tapping Results in Planned Trapping as a Law Enforcement Effort), Juris-Diction, 1(2):708.

16. Article 1 number 1 of Law Number 19 Year 2016 concerning Amendments to Law Number 11 Year 2008 concerning Information and Electronic Transactions

17. Kadarudin. Thamrin, H., Liao, Y. M. (2018). Drug-Related Crimes and Control in Indonesia and Taiwan: Cooperation Regarding Narcotics Smuggling Prevention and Countermeasures from the Point of View of International Law. In: Uden, L., Hadzima, B., Ting, I. H. (eds) Knowledge Management in Organizations. KMO 2018. Communications in Computer and Information Science, vol 877. Springer, Cham, https://doi.org/10.1007/978-3-319-95204-8_27

18. Hari, S., \& Lilik, R. (2003). Hukum Pembuktian Dalam Perkara Pidana (Proof Law in Criminal Cases), Mandar Maju, Bandung, 63. 